\title{
Йодне забезпечення дітей м. Київ
}

\section{В.І. Кравченко', В.С. Березенко ${ }^{2}$, Л.В. Сліпачук², І.А. Лузанчук', О.М. Голінько ${ }^{3}$, Б.К. Медведєв ${ }^{1}$, B.І. Красніков ${ }^{1}$}

'ДУ «Інститут ендокринології та обміну речовин ім. В.П. Комісаренка НАМН України» ${ }^{2}$ Державний медичний університет ім. О.О. Богомольця

${ }^{3}$ Інститут екогігієни та токсикології ім. В.І. Медведя

\begin{abstract}
Резюме. Мета - визначення йодної забезпеченості дітей, які мешкають у м. Київ. Матеріал і методи. Досліджено йодний статус 121 дитини у двох районах м. Київ: 60 дітей у Подільському та $61-$ у Дарницькому. Обстеження учнів 10-12 років проводили за дозволом органів освіти та згодою батьків. Дітям вимірювали зріст, масу тіла, їх оглядав лікар-ендокринолог із визначенням стану щитоподібної залози (Щз). Діти здавали 50 мл ранкової сечі. Сечу перед визначенням йоду зберігали протягом 7-10 днів за -20 $\mathrm{C}$. Визначення вмісту йоду в сечі здійснювали церій-арсенітним методом. За допомогою ультразвукового обстеження Щ3 вимірювали їі розміри та розраховували їх відношення до площі поверхні тіла. Отримані результати порівнювали з відповідними нормами МОЗ України. Результати. За допомогою спеціальної анкети, яку заповнювали батьки дітей, визначали ставлення до проблеми профілактики йодозалежних захворювань, вживання морепродуктів, збагачених йодом препаратів і йодованої солі. Рівень йодної забезпеченості дітей із двох районів був задовільним, медіана йодурії становила 107,23 мкг/л, хоча в 45,4\% випадків діти були в стані йододефіциту слабкого та середнього ступеня. На наявність проблеми йододефіциту вказував інший показник йодної забезпеченості - частота випадків зоба. За даними ультразвукового дослідження, у 20,5\% випадків у дітей було суттєво збільшено розміри ЩЗ, причому серед дівчаток ці зміни виявляли в 3 рази частіше, ніж серед хлопчиків. За даними анкетування, опитані лише у 20,5\% випадків використовували йодовану сіль. Висновок. Йодне забезпечення дітей м. Київ є недостатнім, існує необхідність підвищення рівня споживання йодованої солі.
\end{abstract}

Ключові слова: йодне забезпечення, діти, профілактика йододефіциту.

Майже третина населення планети мешкає в умовах недостатнього харчового споживання йоду, наслідком чого є значне поширення йододефіцитних захворювань у різних країнах світу [1-3], насамперед захворювань щитоподіб-

\footnotetext{
* Адреса для листування (Correspondence): Національний медичний університет імені О.О. Богомольця, бульвар Тараса Шевченка, 13, м. Київ, 01601, Україна. E-mail: 100mib@rambler.ru

(С) В.І. Кравченко, В.С. Березенко, Л.В. Сліпачук, І.А. Лузанчук, О.М. Голінько, Б.К. Медведєв, В.І. Красніков
}

ної залози (ЩЗ) серед різних верств населення. $\mathrm{y}$ дітей це явище є основною причиною поширеної патології - дифузного зоба. Встановлено, що серед районів зі слабким йододефіцитом (ЙД) частота зоба сягає до $20 \%$, із середнім - до $30 \%$, із тяжким - 40\% і більше [4]. Нові критерії оптимальних розмірів ЩЗ у дітей [5] суттєво збільшують показник частоти випадків патології та, акцентуючи увагу на наявності Йд, спри- 
яють його усуненню. В Україні Міністерством охорони здоров'я затверджено оптимальні показники розмірів ЩЗ для дітей, перевищення яких вказує на наявність зоба [6].

Зоб - найпомітніший прояв недостатності споживання йоду, але він є лише верхівкою айсберга. Наступними наслідками недостатності йоду в харчуванні виступають гіпотиреоз, вузлові зміни в ЩЗ і зсуви в інших органах унаслідок порушення синтезу тиреоїдних гормонів. Найважливішим для дітей є їх вплив на психосоматичний розвиток. Реалізація негативних наслідків ЙД починається з ранніх етапів розвитку дитини, починаючи з внутрішньоутробного, та продовжується в наступні періоди [7, 8]. Від внутрішньоутробного ЙД насамперед потерпають слухова, рухова та інші функції головного мозку, пошкоджуються апарат равлика (cochlea), кора головного мозку та базальні ганглії. Зниження інтелекту - найсерйозніший наслідок $[9,10]$. Виділяють тяжкі форми розумової відсталості та пограничні форми зниження інтелектуального розвитку. Тяжкі форми розумової відсталості виникають унаслідок вродженого гіпотиреозу, який розвивається на тлі тяжкого ЙД матері, в організм якої надходить менше від 20 мкг йоду на добу. Якщо цей гіпотиреоз не було вчасно проліковано, він часто супроводжується кретинізмом. Тяжкість пошкодження мозку та ступінь порушень інтелектуальної сфери залежать від етапу онтогенезу, на якому дитина зазнає йодного дефіциту.

Україна, на жаль, - одна з небагатьох країн Європи, де проблему профілактики йододефіцитних захворювань не вирішено. Геологічні особливості території України зумовлюють наявність йодної недостатності в західних і північних регіонах країни. Наші дослідження довели наявність йододефіциту різного ступеня практично на всій території України [11, 12]. Крім дітей, надто потерпають від ЙД вагітні $[13,14]$.

Місто Київ - найбільший мегаполіс країни, де впроваджуються сучасні методи профілактики і де, імовірно, можна очікувати наліпшої ситуації в країні стосовно Йд. Тому метою даної роботи було визначення йодного статусу дітей м. Київ.

\section{Матеріал і методи}

Методом рівномірного розподілу [15] серед учнів 4-5-го класів школи № 8 Подільського району та школи № 272 Дарницького району відібрано 60 та 61 школярів відповідно. Серед обстежених Подільського району було 28 хлопчиків і 33 дівчинки віком від 10 до 12 років, Дарницького району - 33 хлопчики та 27 дівчаток. На проведення дослідження отримано згоду органів освіти відповідних районних адміністрацій, керівництва шкіл і батьків дітей. Під час дослідження дітям вимірювали масу тіла та зріст, їх оглядав лікар-ендокринолог. Діти здавали 50 мл ранкової сечі. Зразки сечі доправляли в ДУ «Інститут ендокринології та обміну речовин ім. В.П. Комісаренка НАМН України», переносили у відповідно промарковані пробірки, закорковували їх та зберігали протягом 7-10 діб за температури $-20{ }^{\circ} \mathrm{C}$ до визначення концентрації йоду. Визначення вмісту йоду в сечі проводили церій-арсенітним методом [16, 17]. Результати трактували згідно з критеріями ВООЗ: нормальним вважається діапазон екскреції йоду із сечею на рівні 100-200 мкг/л, значення екскреції 50100 мкг/л є недостатнім і трактується як йододефіцит легкого ступеня; показники екскреції 2050 мкг/л відповідають йододефіциту середнього ступеня, нижче від 20 мкг/л - тяжкому йододефіциту. Показники екскреції понад 300 мкг/л свідчать про надмірне надходження йоду в організм [4]. Дослідження йодурії проходять постійний зовнішній контроль якості в CDC Центрі, Атланта (США), та мають відповідні сертифікати міжнародного зразка.

Ультразвукові дослідження ЩЗ проводили сканером Terason 2000 із лінійним датчиком із частотою 10 мГц (Terason Ultrasound, Burlington, MA, США). Розміри ЩЗ визначали відповідно до [18], їх співвідносили з віком дітей і площею поверхні тіла. Площу поверхні тіла розраховували за формулою:

$$
\mathrm{x}=\frac{\sqrt{\text { Зріст }+ \text { Маса тіла }}}{3600}[19] \text {. }
$$

Відповідно до індикаторів МОЗ щодо співвідношення розмірів ЩЗ і площі поверхні тіла в дітей [6] встановлювали їі збільшення, що вказувало на наявність зоба.

Для батьків дітей передавали анкети, що містили питання про ставлення до проблеми йододефіциту, про використання в домогосподарствах йодованої солі та споживання йодовмісних препаратів і продуктів, багатих на йод.

Статистичну обробку даних проводили відповідно до вимог доказової медицини та біостатис- 
тики, застосовуючи підходи сучасної неінфекційної епідеміології $[19,20]$ із використанням пакетів програм SPSS11.0. i MedStat [21].

\section{Результати та обговорення}

Обстежували однорідні групи дітей віком 10-12 років Подільського та Дарницького районів м. Київ. Йодний статус оцінювали за показниками йодурії та станом ЩЗ. Дослідження рівня йоду в сечі дітей Подільського району показало значні розходження в індивідуальних показниках, які становили від 22,17 мкг/л до 482,77 мкг/л. Результати дослідження в Подільському районі наведено у вигляді гістограми на рисунку. Майже половина дітей мали йодурію нижче від 100 мкг/л, зафіксовано зсув показників ліворуч, тобто ненормальний їх розподіл.

Гістограма результатів по Дарницькому району та в цілому по двох районах мала подібний характер. У зв’язку із цим дані наведено у вигляді медіани йодурії та частоти випадків результатів у відсотках (табл. 1).

Медіана йодурії по двох районах незначно перевищувала 100 мкг/л, що, за існуючими критеріями, вказує на задовільне йодне забезпечення. Водночас значна кількість дітей були в стані слабкого та помірного йододефіциту, у цілому по двох районах $-45,5 \%$. Показники йодурії значною мірою залежать від харчування, достатня

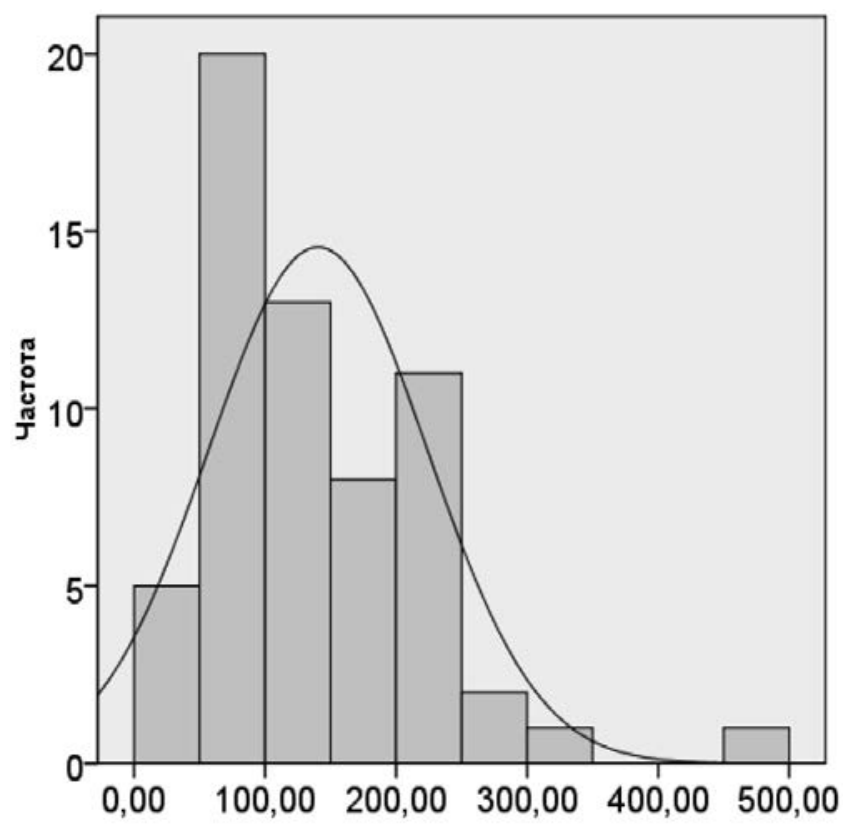

Рис. Розподіл показників йодурії дітей Подільського району. вибірка надає можливість точніше оцінити стан йодного забезпечення.

Розміри ЩЗ відповідали більш сталому рівню йодного забезпечення. Патологічних змін за результатами УЗД у структурі ЩЗ дітей не спостерігалося. Порівняння показників об’єму ЩЗ у дітей різних районів достовірних відмінностей не виявило, як і статевих розбіжностей. Середній об’єм ЩЗ дітей віком 10 років загалом по двох районах становив $5,46 \pm 0,28 \mathrm{~cm}^{3}$,

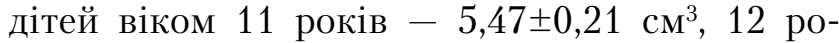
ків $-6,46 \pm 0,32 \mathrm{~cm}^{3}$. Помітної різниці в об'ємах Щ3 у дітей віком 10 і 11 років не спостерігали. У 12-річних дітей об'єм ЩЗ помітно збільшувався порівняно з показниками 10-11-річних дітей $(\mathrm{p}<0,05)$.

За антропометричними характеристиками виявлено певну частку дітей із високим зростом і підвищеною масою тіла в обох вікових групах. Тому для оцінки відповідності розмірів ЩЗ віку дітей використовували верхню межу об’ємів ЩЗ відносно площі поверхні тіла (ППТ), рекомендовану МОЗ України (табл. 2).

Порівняння отриманих результатів 3 індикаторами МО3 показало, що в Подільському районі в 4 хлопчиків і 11 дівчаток було перевищення прийнятих для дітей цього віку найбільших розмірів ЩЗ відносно площі поверхні тіла. Збільшення розмірів ЩЗ понад норму без додаткових змін (вузли, новоутворення, кісти, зміни ехоструктури залози тощо) розглядають як дифузний зоб. У Подільському районі дифузний зоб достовірно частіше виявлено серед

таблиця 1. Екскреція йоду із сечею в дітей

\begin{tabular}{|c|c|c|c|c|c|}
\hline \multirow[t]{2}{*}{ Район } & \multirow{2}{*}{$\begin{array}{l}\text { Кількість } \\
\text { обстеже- } \\
\text { них }\end{array}$} & \multirow{2}{*}{$\begin{array}{l}\text { Медіана } \\
\text { йодурії, } \\
\text { [Q1-Q3] }\end{array}$} & \multicolumn{3}{|c|}{$\begin{array}{l}\text { Розподіл показ- } \\
\text { ників йодурії, \% }\end{array}$} \\
\hline & & & $\begin{array}{l}20- \\
50\end{array}$ & $\begin{array}{l}50- \\
100\end{array}$ & $>100$ \\
\hline Подільський & 60 & $\begin{array}{l}130,45[79,48- \\
191,12]\end{array}$ & 8,2 & 32,8 & 59,0 \\
\hline Дарницький & 61 & $\begin{array}{l}103,52[76,01- \\
148,21]\end{array}$ & 8,3 & 40,0 & 51,7 \\
\hline Загалом & 121 & $\begin{array}{l}107,23[76,89- \\
168,16]\end{array}$ & 8,26 & 37,3 & 54,5 \\
\hline
\end{tabular}

Примітка: [Q1-Q3] - 1-а та 3-я квартилі.

таблиця 2. Верхня межа об'ємів ЩЗ (см³) у дітей відносно площі поверхні тіла $\left(\mathrm{M}^{2}\right)$

\begin{tabular}{|c|c|c|c|c|c|c|c|c|c|c|c|}
\hline ППТ & & 0,8 & 0,9 & 1,0 & 1,1 & 1,2 & 1,3 & 1,4 & 1,5 & 1,6 & 1,7 \\
\hline \multirow{2}{*}{$\begin{array}{l}O \sigma^{\prime} \in M \\
\text { Щ3 }\end{array}$} & хлопчики & 3,4 & 4,2 & 5,0 & 6,7 & 7,6 & 7,6 & 8,4 & 9,3 & 10,2 & 11,3 \\
\hline & дівчатка & 3,3 & 3,8 & 4,2 & 5,0 & 5,7 & 6,5 & 7,6 & 8,6 & 9,9 & 11,2 \\
\hline
\end{tabular}


дівчаток, ніж серед хлопчиків $(\mathrm{p}<0,05)$. Подібні результати отримано й у Дарницькому районі. Серед 60 обстежених у 10 за нормами МОЗ України встановлено зоб. Зареєстровано також статеві відмінності в збільшенні об'ємів ЩЗ. Серед хлопчиків виявлено 3 випадки збільшення Щ3, серед дівчаток -7 ( $<<0,001)$. У цілому по двох районах $(\mathrm{n}=121)$ серед хлопчиків зафіксовано 7 випадків зоба, серед дівчаток - 18, тобто частота випадків зоба серед дівчаток була у 2,57 раза вищою, ніж серед хлопчиків $(\mathrm{p}<0,005)$.

Підсумовані дані ультразвукового обстеження ЩЗ дітей Подільського та Дарницького районів наведено в таблиці 3. Частота їі збільшення понад верхню допустиму норму як у Подільському, так і в Дарницькому районах була досить високою, становивши по двох районах 20,5\%, що відповідає слабкому йодному дефіциту.

3 огляду на ці дані було поставлено завдання з'ясувати ставлення батьків обстежених дітей до йодної профілактики та рівень споживання дітьми йодованої солі і багатих на йод продуктів. Поінформованими стосовно наявності проблеми йододефіциту в Україні виявилися 85\% опитаних. Серед найважливіших джерел інформації виділяють родину, лікарів, вчителів, засоби масової інформації, знайомих. У Подільському районі найвищий відсоток інформації надійшов від родини (33,3\%) і знайомих $(11,6 \%)$, із радіо та телебачення $-11,6 \%$; на жаль, від лікарів і вчителів - лише 8,3\% і 6,6\% відповідно. Дещо інша картина стосовно джерела інформації спостерігалась у Дарницькому районі: від родичів і лікарів інформацію було отримано у $28,6 \%$ і 19,67\% відповідно, у 19,67\% випадків батьки дізналися про ЙД із радіо та телебачення, у 4,92\% - від вчителів, у 8,2\% від знайомих. Також варто зауважити, що лише в одному випадку інформацію отримували з друкованих видань.

таблиця 3. Частота випадків зоба (\%) серед дітей за нормативами МОЗ України

\begin{tabular}{llllll}
\hline Район & $\begin{array}{l}\text { Кіль- } \\
\text { кість } \\
\text { обсте- } \\
\text { жених }\end{array}$ & $\begin{array}{l}\text { вистода } \\
\text { в хлопча }\end{array}$ & $\begin{array}{l}\text { Частота } \\
\text { випадків } \\
\text { зоба в ді- }\end{array}$ & $\begin{array}{l}\text { Частота } \\
\text { випад- } \\
\text { ків зоба }\end{array}$ \\
\hline Подільський 60 & 12,5 & 37,9 & $<0,05$ & 24,6 \\
Дарницький & 61 & 9,1 & 25,9 & $<0,001$ & 16,6 \\
Загалом & 121 & 10,77 & 32,1 & $<0,005$ & 20,5 \\
\hline
\end{tabular}

Ситуація зі споживанням препаратів із вмістом йоду та йодованої солі по досліджених районах суттєво різнилась. Так, у Подільському районі основним засобом профілактики вказали морепродукти $-66,67 \%$, із них постійно (1-2 рази на тиждень) їх вживали $15 \%$ респондентів, а періодично (1-2 рази на місяць) $-51,66 \%$. Основний засіб масової йодної профілактики - йодовану сіль - вживали лише 2 особи з 60-3,33\%. Зовсім інша ситуація спостерігалась у Дарницькому районі. Йодовану сіль загалом використовували для приготування їжі $37,7 \%$, із них постійно - 52,17\%, періодично $47,83 \%$. На нашу думку, поясненням цього є більша участь лікарів у роз'яснювальній роботі серед батьків і дітей у Дарницькому районі проти Подільського - 19,6\% проти 8,3\%. Для ефективного запобігання ЙД захворюванням ВООЗ рекомендує використання йодованої солі щонайменше у 85-90\% домогосподарств. У даному дослідженні таких домогосподарств виявилося лише $20,5 \%$.

Отже, за даними дослідження йодурії, стану Щ3 і рівня споживання йодованої солі в школярів двох районів м. Київ можна констатувати недостатність йодного забезпечення дітей. Проблема йодного забезпечення населення України вивчається нами протягом майже 20 років. На початку цих досліджень лише 0,5\% населення України споживали йодовану сіль, і в різних регіонах України спостерігали йододефіцит різного ступеня: тяжкий, середнього ступеня та легкий, лише в окремих населених пунктах йодне забезпечення було в межах норми. Після прийняття Кабінетом Міністрів України Державної програми профілактики йодозалежних захворювань на 2002-2005 роки ситуація з йодною профілактикою суттєво змінилася. Більшість населених пунктів перебували в зоні слабкого йодного дефіциту, з'явилося багато населених пунктів із нормальним йодним забезпеченням, суттєво зменшилася їх кількість із середнім i тяжким ЙД. За результатами національного дослідження мікроелементного споживання, здійсненого фахівцями Інституту ендокринології та обміну речовин ім. В.П. Комісаренка НАМН України та Інституту медицини праці НАМН України, споживання йодованої солі населенням в окремих досліджених кластерах досягло 50-90\% населення. Відповідно рівень йодурії суттєво збільшився, медіана екскреції йоду 
в цих населених пунктах досягла 130-145 мкг/л. У цілому ж по Україні споживання йодованої солі в обстежених домогосподарствах становило 25,9\%. По м. Київ медіана йодурії становила 82,2 мкг/л, 23,1\% опитаних (за даними аналізу харчової солі, принесеної з домогосподарств) використовували йодовану сіль $[11,23]$. На жаль, як показали наші дослідження, споживання йодованої солі як основного засобу йодної профілактики наступними роками та наразі в м. Київ залишилося майже на цьому ж рівні.

\section{Висновки}

1. Більшість обстежених дітей Подільського та Дарницького районів м. Київ мали достатнє йодне забезпечення, медіана йодурії становила 107,23 мкг/л, натомість у 44,5\% випадків виявлено слабкий і середнього ступеня йододефіцит.

2. У 20,5\% випадків серед дітей виявлено збільшення об'єму щитоподібної залози, що свідчить про наявність йодної недостатності слабкого ступеня.

3. Збільшення щитоподібної залози серед дівчаток зафіксовано втричі частіше, ніж серед хлопчиків.

4. Для йодної профілактики в домогосподарствах використовували морепродукти та йодовану сіль, рівень використання йодованої солі був недостатнім і становив близько $20 \%$.

5. Вимагає уваги посилення роз'яснювальної роботи лікарів в інформації населення щодо наслідків йододефіциту та необхідності споживання йодованої солі.

6. Для нормалізації йодного забезпечення та поліпшення стану щитоподібної залози рекомендується збільшити споживання населенням йодованої солі.

\section{Список використаної літератури}

1. Hetzel BS. Iodine deficiency disorders (IDD) and their eradication. Lancet. 1983; 2(8359):1126-9.

2. WHO, Global Database on Iodine Deficiency «Iodine status worldwide». Geneva; 2004. 48 p.

3. Pearce EN, Anderson M, Zimmerman MB. Global iodine nutrition: where do we stand in 2013? Thyroid. 2013;23(5):1-6.

4. WHO, UNICEF, and ICCIDD. Assessment of the iodine deficiency disorders and monitoring their elimination. Geneva: WHO, WHO. Euro Nut. 2001. 1-107.

5. Zimmermann MB, Hess SY, Molinari L, de Benoist B, Delange F, Braverman LE, et al. New reference values for thyroid volume by ultrasound in iodine-sufficient schoolchildren: a World Health Organization/Nutrition for Health and Development
Iodine Deficiency Study Group Report. Am J Clin Nutrit. 2004; 79(2):231-7.

6. Наказ Міністерства охорони здоров'я України № 254 від 27.04 .2006 «Про затвердження протоколів надання медичної допомоги дітям за спеціальністю «Дитяча ендокринологія». 109 c. (Order of the Ministry of Health of Ukraine No. 254 of April $27,2006 \ll$ On approval of protocols for providing medical care to children in the specialty«Dytyacha endokrynolohiya. 109 p.).

7. Glinoer D. Maternal and fetal impact of chronic iodine deficiency. Clin Obstet Gynecol. 1997; 1(40):102-16.

8. Glinoer D. Clinical and biological consequences of iodine deficiency during pregnancy (Review). Endocr Dev. 2007; 10:62-9.

9. Bernal J. Thyroid hormones and brain development. In: Pfaff D, Arnold A, Fahbrach S, Moss R, editors. Hormones brain and behavior. Academic Press; 2002. 543-87.

10. Knudsen N, Bülow I, Laurberg P, Ovesen L, Perrild H, $\mathrm{J}$ rgensen T. Low socio-economic status and familial occurrence of goiter are associated with a high prevalence of goiter. Eur J Epidemiol. 2003;18(2): 175-81.

11. Кравченко ВI, Ткачук ЛА, Турчин ВI, Лузанчук IА, Тронько МД, Миронюк НІ, та ін. Споживання йодованих продуктів та стан йодної забезпеченості населення України. Доповіді НАН України. 2005; 10:188-94. (Kravchenko VI, Tkachuk LA, Turchyn VI, Luzanchuk IA, Tron'ko MD, Myronyuk NI, et al. Consumption of iodinated products and the state of iodine supply of the population of Ukraine. Dopovidi NAN Ukrayiny. 2005; 10:188-94).

12. Тронько НД, Мабучи К, Кравченко ВИ, Хатч М, Лихтарев ИА, Мак КР, и др. Йодный статус и дозы облучения щитовидной железы у пострадавших вследствие Чернобыльской катастрофы, проживающих в северных регионах Украины (украинско-американское когортное исследование). Журнал Національної академії медичних наук України. 2013;19(3):355-66 (Tron'ko ND, Mabuchi K, Kravchenko VI, Khatch M, Likhtarev IA, Mak KR, et al. Iodine status and thyroid doses in the Chernobylaffected people living in the northern regions of Ukraine (Ukrainian-American cohort study). Zhurnal Natsíonal'noí akademíi medichnikh nauk Ukraíni. 2013;19(3):355-66).

13. Тананакіна НВ, Кравченко ВI, Бєлкіна ОВ, Маландій ЄВ. Йодна профілактика та рівень інформованості вагітних жінок південно-східного регіону України щодо попередження йодозалежних захворювань. Перинатологія та педіатрія. 2009;3(39):39-44 (Tananakina NV, Kravchenko VI, Byelkina OV, Malandiy YeV. Iodine prevention and level of awareness of pregnant women in the southeastern region of Ukraine regarding the prevention of iodine-dependent diseases. Perynatolohiya ta pediatriya 2009;3(39):39-44)

14. Лузанчук IA, Кравченко ВI, Медведєв БК. Йодне забезпечення та стан йодної профілактики серед вагітних. Ендокринологія. 2016;21(1):38-44. (Luzanchuk IA, Kravchenko VI, Medvedyev BK. Iodine supply and iodine prevention among pregnant women. Endokrynolohiya. 2016;21(1):38-44).

15. Assessment of iodine deficiency disorders and monitoring their elimination: a guide for programme managers. 3rd ed. WHO, Geneva, Switzerland; 2007. 97 p.

16. Sandell EB, Kolthoff IM. Micro determination of iodine by a catalytic method. Microchemica Acta. 1937; 1(1):9-25.

17. Dunn JT, Grutchfield HE, Cutekunst R, Dunn AD. Methods for measuring iodine in urine. The Netherlands: International Council for Control of Iodine Deficiency Disorders, 1993:7-16.

18. Volumetrie der Schildrusenlappen mittels real-time sonographie / Brunn J, Block U, Ruf J, Kunze WP, Scriba PC. Deutsche Medizinische Wochenschrift. 1981;106(41):1338-40.

19. Mosteller RD. Simplified calculations of body surface area. N Engl J Med. 1987; 37 (17):1098.

20. Биглхол Р, Бонита $\mathrm{P}$, Кьельстрём T, редакторы. Основы эпидемиологии. Женева: BO3;1994. 259 c. (Biglkhol R, Bonita R, K'yel'strom T, editors. Basics of epidemiology. Geneva: WHO 1994. 259 c.).

21. Власов ВВ. Введение в доказательную медицину. Москва: Медиа Сфера; 2001. 392 с. (Vlasov VV. Introduction to evidencebased medicine. Moskva: Media Sfera; 2001.392 p.).

22. Лях ЮЕ, Гурьянов ВГ. Анализ результатов медико-биологических исследований и клинических испытаний в специа- 
Оригінальні дослідження

лизированном статистическом пакете MEDSTAT. Вестник гигиены и эпидемиологии. 2004; 8(1):155-67. (Lyakh YuYe, Gur'yanov VG. Analysis of the results of biomedical research and clinical trials in the specialized statistical package MEDSTAT. Vestnik gigiveny i epidemiologii. 2004; 8(1):155-67).

23. Кравченко ВI, Каракашян АН, Луб'янова ІП, Калачова ІВ. Звіт про національне дослідження вживання населенням харчових мікронутрієнтів: Україна. Київ: Прем'єр Медіа; 2004. 70 с. (Kravchenko VI, Karakashyan AN, Lub'yanova IP, Kalachova IV. Report on a national population micronutrient consumption survey: Ukrayina. Kyyiv: Prem'yer Media; 2004. 70 p).

(Надійшла до редакиії 04.08.2019 р.)

\section{Йодное обеспечение детей г. Киев}

\section{В.И. Кравченко ', В.С. Березенко², Л.В. Слипачук², И.А. Лузанчук ${ }^{1}$, О.М Голинько ${ }^{3}$, Б.К. Медведев ${ }^{1}$, B.И. Красников ${ }^{1}$}

${ }^{1}$ ГУ «Институт эндокринологии и обмена веществ им. В.П. Комиссаренко НАМН Украины»

${ }^{2}$ Государственный медицинский университет им. А.А. Богомольца

${ }^{3}$ Институт экогигиены и токсикологии им. В.И. Медведя

Резюме. Цель - исследовать йодную обеспеченность детей, проживающих в г. Киев. Материал и методы. Исследован йодный статус 121 школьника по 2 районам г. Киев. Обследованы 60 детей в Подольском и 61 в Дарницком районе. Обследование учащихся 10-12 лет проводили с разрешения органов образования и роди телей. Детям измеряли рост и массу тела, обследовали щитовидную железу (ЩЖ), их осматривал врач-эндокринолог. Дети сдавали 50 мл утренней мочи, которую хранили в течение 7-10 дней при $-20{ }^{\circ} \mathrm{C}$ до определения йода, которое осуществляли церийарсенитным методом. С помощью ультразвукового обследования щитовидной железы измеряли ее размеры и рассчитывали отношение ее объема к площади поверхности тела. Результаты. Полученные результаты сравнивали с соответствующими нормами Минздрава. С помощью специальной анкеты, которую представляли родителям детей, определяли их отношение к проблеме профилактики йододефицитных заболеваний, употреблению морепродуктов, препаратов, обогащенных йодом, и йодированной соли. Уровень йодной обеспеченности детей из двух районов был удовлетворительным, медиана йодурии составляла 107,23 мкг/л, хотя 45,4\% детей находились в зоне йододефицита легкой и средней степени. На наличие проблемы йододефицита указывал другой показатель йодной обеспеченности - частота случаев зоба. По данным ультразвукового исследования 20,5\% детей имели существенно увеличенные размеры щитовидной железы, причем у девочек эти изменения наблюдались в 3 раза чаще, чем у мальчиков. По данным анкетирования, только 20,5\% опрошенных использовали йодированную соль. Выводы. Йодное обеспечение детей г. Киев является недостаточным, необходимо увеличение уровня потребления йодированной соли.

Ключевые слова: йодная обеспеченность, дети, профилактика йодного дефицита.

\section{lodine providing Kyiv children}

\author{
V.I. Kravchenko', V.S. Berezenko ${ }^{2}$, L.V. Slipachuk², \\ I.A. Luzanchuk', O.M. Golin'ko³, B.K. Medvedev', \\ V.I. Krasnikov ${ }^{1}$ \\ ${ }^{1}$ «V.P. Komisarenko Institute of Endocrinology and Metabolism, Natl. Acad. \\ Med. Sci. of Ukraine», Kyiv \\ ${ }^{2}$ O.O. Bogomolets National Medical University \\ ${ }^{3}$ Institute of Ecohygiene and Toxicology named after V.I. Medvedia
}

Abstract. The aim - determination of iodine providing Kyiv children. Material and methods. The iodine status of 121 children in $2 \mathrm{~m}$ districts of Kyiv is investigated. 60 children were surveyed in Podolsky and 61 in Darnytsky district. The examination of students aged 1012 years was carried out by selecting the children by the method of even distribution by the permission of the educational authorities and the consent of the parents. All the subjects were weighed, measured the height, examined the doctor endocrinologist, and examined the thyroid gland. The children were given $50 \mathrm{ml}$ morning urine. The urine was transferred to appropriately signed tubes, sealed them and stored for about 7-10 days at $-20{ }^{\circ} \mathrm{C}$ until iodine was detected. Determination of iodine content in the urine was carried out by cerium-arsenic method. Using ultrasound examination of the thyroid gland, its dimensions were measured and their relation to the surface area of the body was calculated. Results. The obtained results were compared with the relevant indicators of the Ministry of Health. With the help of a special questionnaire, which was provided to parents of children, they determined the relation to the problem of prevention of iodine-dependent diseases, the use of seafood, preparations enriched in iodine and iodized salt. The level of iodine supply of children from two districts was satisfactory, median iodine was $107.23 \mu \mathrm{g}$ l, although $45.4 \%$ of children were in the zone of iodine deficiency of weak and medium severity. The presence of a problem indicated iodine deficiency was indicated by another indicator of iodine availability - the frequency of goiter. According to ultrasound data, $20.5 \%$ of children had significantly increased thyroid gland size, with girls having these changes being 3 times more frequent than boys. According to the survey data, only $20.5 \%$ of respondents used iodized salt. Conclusion. The conclusion is made about insufficient iodine maintenance of children of Kyiv and the need to increase consumption of iodized salt.

Keywords: children, iodine providing, iodine insufficient prophylactic. 